\title{
Ban of jatka (Juvenile Hilsa Fish) Catching: Views and Coping Options of Artisanal Fishers in Coastal Bangladesh
}

\author{
Mohammed Mamun Rashid \\ Community Development Centre (CODEC), Chittagong, Bangladesh
}

Email address:

rashidmamuns@yahoo.com

To cite this article:

Mohammed Mamun Rashid. Ban of jatka (Juvenile Hilsa Fish) Catching: Views and Coping Options of Artisanal Fishers in Coastal Bangladesh. American Journal of Biological and Environmental Statistics. Vol. 2, No. 4, 2016, pp. 34-40. doi: 10.11648/j.ajbes.20160204.12

Received: December 2, 2016; Accepted: December 10, 2016; Published: January 10, 2017

\begin{abstract}
This paper examines adverse effects at lives and livelihoods of traditional Hindu fishermen and Muslim fishermen due to periodical restriction on jatka (juvenile hilsa fish) catching in coastal Bangladesh. A total of 100 respondents from both religious groups were purposively selected from four study sites. Traditionally, the Jaladas (slave of the water) were engaged in the fishing profession who belonging to the Hinduism and one of low caste-bound people. They are being put under pressure by incoming Muslims who take up fishing as their profession. This study finds that though Hindu fishermen seriously face dimensions of abject poverty but majority of them follow government rule where Muslim fishers don't care. In coping strategies, majority of Hindu fishermen have psycho-social barrier to change fishing profession. Their coping options are also limited than Muslim fishermen. This paper suggests that policy instruments and fishery management of Bangladesh should give special focus on socio-economic \& cultural aspects of those downtrodden people for inclusive development.
\end{abstract}

Keywords: Bangladesh, Coping Options, Fishermen, Lives and Livelihoods, Wellbeing

\section{Introduction}

Fisheries and aquaculture is a source not just of health but also of wealth. Employment in the sector has grown faster than the world's population. The sector provides jobs to tens of millions and supports the livelihoods of hundreds of millions [1]. FAO also recognizes the important contribution that small-scale fisheries make to global poverty alleviation and food security. Governance of fisheries has been weak around the world, and this has resulted in an excess of capacity in the fishing industry, overfishing, and a vast loss of economic returns [2]. Bangladesh, the world's largest deltaic zone, is crisscrossed by big rivers, and their tributaries and distributaries. Moreover, as a land with an abundance of torrential monsoon rains, most of the plain-lands remain inundated during the monsoon season, thus turning the countryside into a big reservoir of fresh water for almost half of the year. These huge, inland, sweet water bodies together with the expanse of saline water in the Bay of Bengal provide the basis for a large and diversified fisheries sector. Fisheries have always been an inseparable part of lives and livelihoods of the people of Bangladesh. Fisheries of Bangladesh fall broadly into three main categories: inland capture, inland culture and marine fisheries.

Fisheries sector of Bangladesh contributes 3.68\% to the national Gross Domestic Product (GDP) in 2012-2013 [3]. Fish provides $60 \%$ of national animal protein consumption [4]. Fisheries sector also plays an important role in rural employment generation and poverty alleviation. It provides employment for millions of rural people, supply a crucial and cheaper source of protein for the poor and generate cash from sales of fish [5].

Defining small-scale and artisanal fisheries is a challenge as the terms have been used for decades by fishery politicians and administrators, legal officers, biologists, economists, sociologists, engineers, fishers, non-governmental organizations and the media to represent different points of view and socio-economic dimensions in different national contexts. Trying to combine all the characteristic dimensions of these fisheries, the FAO glossary indicates that artisanal 


\section{fisheries are:}

"traditional fisheries involving fishing households (as opposed to commercial companies), using relatively small amount of capital and energy, relatively small fishing vessels (if any), making short fishing trips, close to shore, mainly for local consumption. In practice, definition varies between countries, e.g. from gleaning or a one-man canoe in poor developing countries, to more than $20-\mathrm{m}$. trawlers, seiners, or long-liners in developed ones. Artisanal fisheries can be subsistence or commercial fisheries, providing for local consumption or export. They are sometimes referred to as small-scale fisheries".

Small-scale fisheries (used as synonym for artisanal fisheries) are not only a source of livelihood for the rural fishers, but also an 'art of living' that is characterized by a long tradition of adaptation to the dynamics of the social and natural environment. The small-scale fisheries in Bangladesh are mostly open access and unregulated. For obvious reasons, where labor mobility in a denselypopulated society is not impeded by legal, social, political and other factors, low-skilled poor people are expected to enter open access fisheries as long as incomes from similar economies are lower than those in the fisheries [6]. Alam [7] cites that.

Population increase together with the increasing landlessness caused by land erosion and nagging poverty has changed the structure of the agricultural sector and thereby also the small-scale fisheries sector. The arable land has been divided into smaller and smaller units, often so small that they cannot support a family. Fishing has then become an alternative source of employment, part time or full time, for poor and landless peasants living in the riverine and coastal areas of Bangladesh. Small-scale fishery is seen as a last resort to earn one's livelihood.

Traditionally, low caste Hindu was engaged in the fishing profession. The Jaladas (slave of the water) are from fisherfolk communities belonging to the Hinduism and one of caste-bound people. In most of the cases they live in segregated paras (a set of households which may be relatively autonomous from the village in terms of primary social relations and/or kinship), which are localities within a village. The high caste Hindu and the Muslim aristocracy and gentry carefully avoid any social mingling with them. Traditional fishing communities, which are mainly Hindu, are being put under pressure by incoming Muslims who take up fishing as their profession. The newcomers are either self-employed or find employment as laborers. Majority of Muslim penetrate in fishing due to population pressure, economic constraints in agricultural sector, and adverse effects of climate change. Habib [8] states the Hindu Jaladas, religiously minority in Bangladesh, believe that it is not easy for them to switch to other professions. This is a sociopsychological barrier. They consider themselves sinners as they earn their living by catching innocent fishes. They identify themselves as 'servants of water' without hesitation. They also believe they are destined to carry this curse in their whole life.

Bangladesh Centre for Advanced Studies [9] cites that for protection, conservation and biological management of inland and marine capture fisheries resources there exist some act/ordinance, laws and regulations such as: (i) restriction of size of some species of fishes for catching for certain period of a year, (ii) restriction on some fishing gears/devices, (iii) restriction on mesh size of fishing nets, (iv) restriction/ban on fishing area and period for any or all gears for certain period, and (v) regulation for allocation of marine fishing area for artisanal and industrial fishing and other marine fisheries laws and regulations.

According to fisheries law of Bangladesh, jatka is defined as juvenile hilsa fish generally up to 23 centimeters (cm) in length; and it is prohibited to catch from Kartik (Mid October- Mid November) to Baisakh (Mid April- Mid May). Beside this, the mesh size below 4.50 centimeters (cm) is also prohibited to use for catching jatka. Based on primary research done by author, an overview of fisheries resources is given in this study. This paper examines how imposed restriction on jatka catching affects lives and livelihoods of traditional Hindu fishermen and Muslim fishermen who are religiously different and living at distinct geographical setting. It also describes how both types of artisanal fishers cope and its scope to respond with their changed situation.

\section{Methods and Materials}

This research adopts a mixed method, applying both qualitative and quantitative methodologies in collecting, assessing and analysis data. Total 100 artisanal fishermen were purposively selected from four coastal villages of Bangladesh. A total of $50 \mathrm{Hindu}$ fishermen were selected from Kumira and North Salimpur fishing villages under Sitakunda upazila (sub-district) in Chittagong district. They are engaged for marine fishing from generation to generation. Other 50 Muslim fishermen were selected from Tatul Baria and Nizampur villages of Barguna and Patuakhali districts respectively. They usually catch fishes from Payra river, Andermanik river, estuary and sea. The questionnaire for the survey centered on causes of catching jatka, income, loan patter, government and non-government supports, and alternative livelihoods.

Map of study site- 


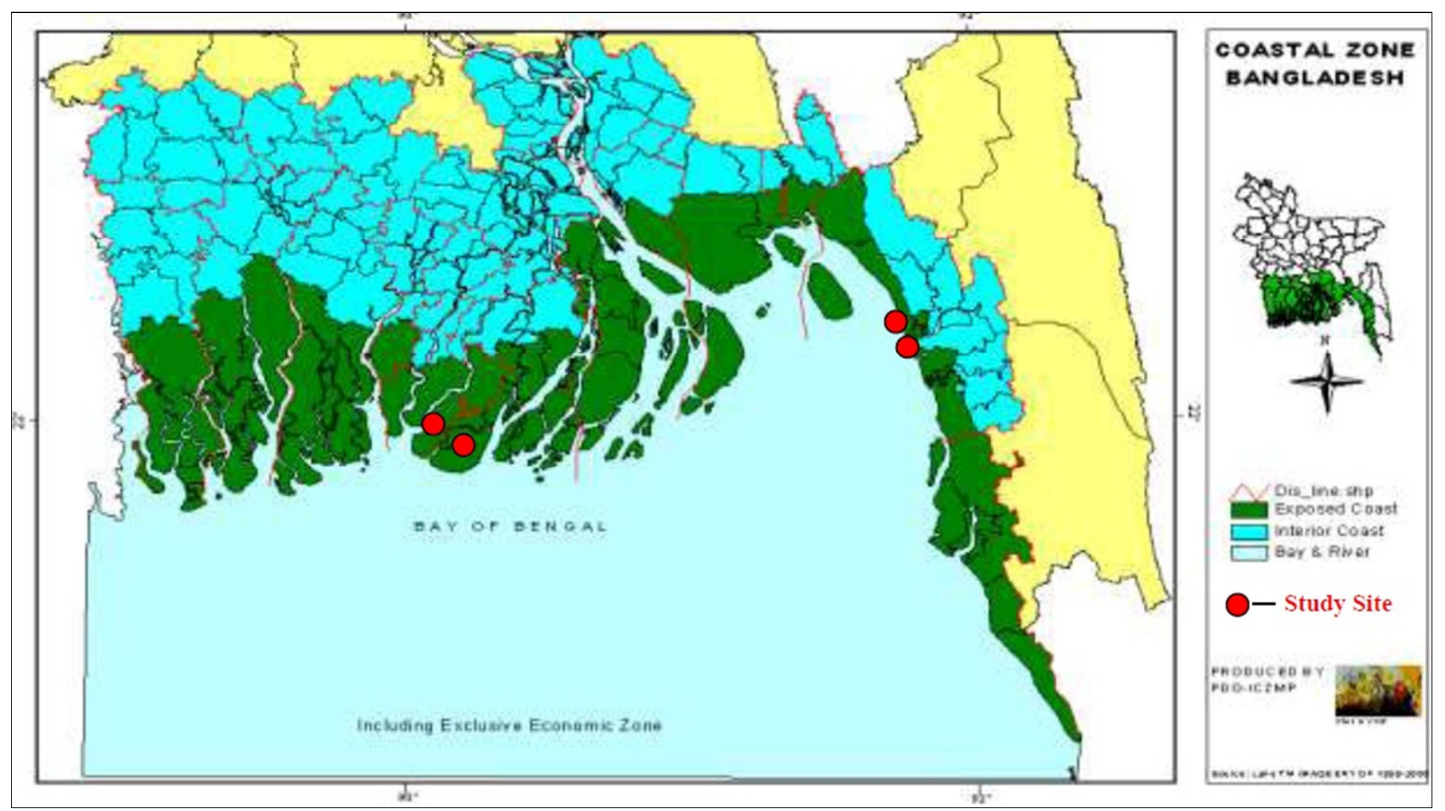

Fig. 1. Map of Coastal Area and Study Site.

\section{Results and Discussions}

\subsection{Fisheries in Bangladesh}

Table 1 shows that total fish production was 3,410,254 metric tons in 2012-2013. Figure 2 represents an increasing trends of fish production over last ten years comparing from 2003-2004, that is, 2,102,026 metric tons; but its contribution to national GDP is very slightly increased relating with other sub-sectors.

Table 1. Annual Fish Production in Inland and Marine Fisheries (2012-2013) of Bangladesh.

\begin{tabular}{lll}
\hline Sector of Fisheries & Total Production (Metric Ton) & Percentage \\
\hline A. Inland Fisheries & - & - \\
(i) Inland Open Water (Capture) & 961,458 & $28.19 \%$ \\
(ii) Inland Closed Water (Culture) & $1,859,808$ & $54.54 \%$ \\
B. Marine Fisheries & - & - \\
(i) Industrial (Trawl) & 73,030 & $2.14 \%$ \\
(ii) Artisanal & 515,958 & $15.13 \%$ \\
Country Total & $3,410,254$ & $100 \%$ \\
\hline
\end{tabular}

Source: Department of Fisheries (DoF) 2014, Bangladesh [10]

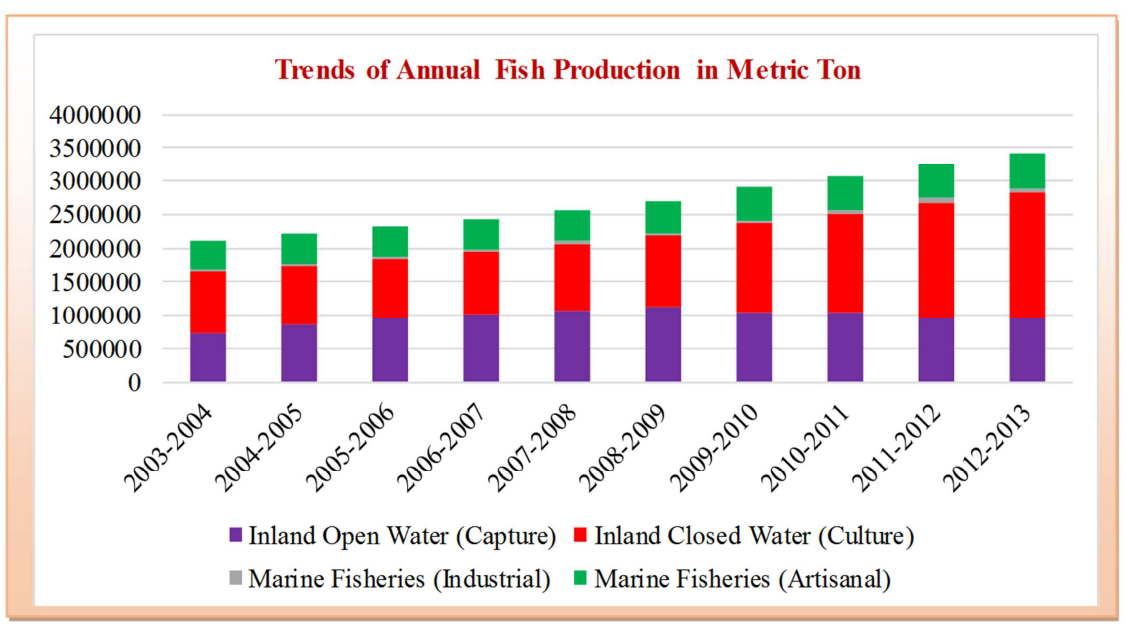

Source: Department of Fisheries (DoF), Bangladesh; and comparison by author

Fig. 2. Trends of Annual Fish Production in Metric Ton. 
Figure 2 also reveals that production from inland culture significantly increased i.e. from $43.52 \%$ to $54.54 \%$ of total country production during last ten years. Sixth Five Year Plan (2011-2015) of Planning Commission in Bangladesh [11] cites that the small-scale open water capture fisheries which was dominant in the 1970s has given way to close water culture fisheries, which is now playing an important role in the development of the sub-sector. However, there are inadequate institutional arrangements and commitments to integrate fisheries into the planning, designing and operations. The Department of Fisheries (DoF) is suffering from lack of manpower, particularly at the field levels. Fish preservation, processing and marketing structure, particularly for the capture fisheries, are also weak.
Bangladesh has a coastline of 710 kilometers and an Exclusive Economic Zone (EEZ). There are different views on the delimitation of the coastal areas. The conventional view is that the land that is inundated by the high and low tides is called the coastal belt. Coastal zones refer to areas where land and sea meet. Three indicators have been considered for determining the landward boundaries of the coastal zone of Bangladesh. These are: influence of tidal waters, salinity intrusion and cyclones/storm surges. Total 19 districts of the country are being affected directly or indirectly by some of these phenomena. Table 2 indicates that coastal districts have significant contribution for fish production (capture) in inland water.

Table 2. Annual Fish Production (Capture) in Inland Water for 2012-2013.

\begin{tabular}{llllll}
\hline \multirow{2}{*}{ Categories } & \multicolumn{2}{l}{ In Metric Ton } & & & \\
\cline { 2 - 6 } & River & Sundarbans & Beel & Kaptai Lake & Flood Plain \\
\hline Bangladesh & 147,264 & 15,945 & 87,902 & 9,017 & 701,330 \\
Coastal Districts & 124,377 & 15,945 & 2,396 & 0 & 210,274 \\
Percentage & $84.46 \%$ & $100 \%$ & $2.73 \%$ & $0 \%$ & 352,992 \\
\hline
\end{tabular}

Source: Department of Fisheries (DoF) 2014, Bangladesh; and calculation by author

Hilsa is most valuable species with annual catch of $340,000 \mathrm{MT}$, and income valued at \$US 1.3 billion per year [12]. At present $50-60 \%$ of global hilsa catch takes place in the coastal and marine waters of Bangladesh, $20-25 \%$ in Myanmar, $15-20 \%$ in India and the remaining 5-10\% in other countries. However, the Government of Bangladesh (GoB) usually provides 120 kilograms rice to each fishing family during jatka catching banning period. In 2012-2013, a total of 206,229 fishing families in 16 districts received this compensation. Jatka preservation, sanctuary management, and protection of mother hilsa increase hilsa fish production (Ministry of Finance 2014).

\subsection{Jatka Catching}

Total 92 percent of Muslim fishermen don't obey jatka catching restriction imposed by government. On the other hand, only 20 percent Hindu fishermen don't obey this rule.
It has been observed that majority of Hindu fishermen usually use Tong nets (gill nets) for hilsa, and Behundi nets (set-bag nets) for other species. However, they have to travel more and more for catching jatka. Muslim fishers rampantly use current nets (monofilament nets) to catch jatka and it also available at their fishing grounds. Abject poverty is the main cause of jatka catching. Table 3 identifies causes of jatka catching by fishers with multiple answers.

Poverty in fishing community is multidimensional that usually include declining fish catches, lack of security (mainly in the fishing grounds due to piracy), natural disasters such as cyclones or floods, lack of capital, lack of employment opportunities, and lack of health \&education/skills. It is revealed that though Hindu fishermen seriously face abject poverty but majority of them follow government rule due to friendly behavior on ecological services and fear of law enforcing agency.

Table 3. Causes to catch jatka.

\begin{tabular}{lllll}
\hline \multirow{2}{*}{ Causes of jatk catching } & Hindu fishermen & & Muslim fishermen \\
\cline { 2 - 5 } & Frequency & Rank & Frequency & Rank \\
\hline To maintain family expenses & 10 & 1 & 40 & 1 \\
To pay instalment of loan & 7 & 2 & 38 & 2 \\
Pressure from local moneylenders & 5 & 3 & 25 & 3 \\
Availability of monofilament nets & - & - & 22 & 4 \\
Education of children & - & - & 20 & 5 \\
Availability of $j$ jatka & - & - & 15 & 6 \\
Uncertainty to get hilsa during peak season & - & - & 8 & 7 \\
For medicine of family members & - & - & 6 & 8 \\
Lack of awareness & - & - & 5 & 9 \\
Encouraged by other fishermen & - & - & 4 & 10 \\
\hline
\end{tabular}




\subsection{Income}

In Hindu fishing communities of study area, Srabon (Mid July to Mid August), Bhadro (Mid August to Mid September), and Aswin (Mid September to Mid October) comes round the year as a main season of catching hilsa. Table 4 indicates that income of Hindu fishermen is comparatively higher than Muslim fishermen during hilsa season. On the other hand, income of Hindu fishermen is significantly lower during jatka catching restriction period as proved in Table 5. Hindu fishermen state that industrial fishing trawlers by commercial entrepreneurs seriously destruct fisheries resources and push their livelihoods at risk. Moreover, their livelihood options are also limited compare to Muslim fishermen.

Table 4. Daily income distribution during fishing season.

\begin{tabular}{|c|c|c|c|c|}
\hline Income in Taka $(\mathrm{N}=100)$ & Hindu fishermen & $\%$ & Muslim fishermen & $\%$ \\
\hline Less than 100 & - & - & - & - \\
\hline $100-199$ & - & - & 2 & 4 \\
\hline $200-299$ & 1 & 2 & 2 & 4 \\
\hline $400-499$ & 19 & 38 & 16 & 32 \\
\hline 500 and up & 16 & 32 & 13 & 26 \\
\hline Total & 50 & 100 & 50 & 100 \\
\hline
\end{tabular}

Table 5. Daily income distribution during jatka catching restriction period.

\begin{tabular}{|c|c|c|c|c|}
\hline Income in Taka $(N=100)$ & Hindu fishermen & $\%$ & Muslim fishermen & $\%$ \\
\hline Less than 100 & 19 & 38 & 7 & 14 \\
\hline $100-199$ & 26 & 52 & 14 & 28 \\
\hline $200-299$ & 5 & 10 & 11 & 22 \\
\hline $300-399$ & - & - & 9 & 18 \\
\hline $400-499$ & - & - & 6 & 12 \\
\hline 500 and up & - & - & 3 & 6 \\
\hline Total & 50 & 100 & 50 & 100 \\
\hline
\end{tabular}

\subsection{Government and Non-government Supports}

Majority (86 percent) of fishing family received 120 kilograms rice from government during jatka catching restriction period. It is found that Hindu and Muslim fishermen had equal access to receive such support. Muslim fishermen received training on aquaculture, cow fattening, and homestead gardening from the government. Hindu fishermen are seriously deprived from government training. In NGO perspective, different NGOs provide financial and capacity building supports for Muslim fishermen. However, only one NGO, Community Development Centre (CODEC) - DANIDA funded; started work for health, education, financial support of Hindu fishing communities since long. Nowadays, few NGOs also work for Hindu fishermen especially in the areas of microfinance.

\subsection{Loan Pattern}

Table 6 shows that most of the respondents (96 percent) received loan from formal and informal sources. Muslim fishermen have higher access to formal bank because it relating to land collateral. All Hindu fishermen are landless though one of them managed loan from government bank by an acquainted Muslim. Alam (1996) mentions the traditional Hindu fishermen are used to taking loans to ensure social security. The fishermen ensure social security while receiving the loan especially from dadandar (one who makes advance payments as loans against catches). It becomes a part of the duty of the moneylenders to save the borrowers from distress, mainly physical and communal, to secure their money. Now Hindu fishermen predict that amount of dadan has been decreased due to depletion of fish catches. In addition, they have opportunity to receive loan from NGOs. All fishermen criticize that majority of NGOs give them only loan rather than capacity building trainings and linkage.

Table 6. Loan position of fishermen.

\begin{tabular}{lllll}
\hline Loan in Taka $(\mathbf{N}=\mathbf{1 0 0})$ & Hindu fishermen & $\mathbf{\%}$ & Muslim fishermen & $\mathbf{\%}$ \\
\hline No loan & - & - & 2 & 4 \\
$1-29,999$ & 5 & 10 & 3 & 6 \\
$30,000-59,999$ & 8 & 16 & 10 & 20 \\
$60,000-89,999$ & 4 & 8 & 3 & 6 \\
$90,000-119,999$ & 12 & 24 & 5 & 10 \\
$120,000-149,999$ & 8 & 16 & 5 & 10 \\
$150,000-179,999$ & 6 & 12 & 7 & 14 \\
$180,000-209,999$ & 5 & 10 & 4 & 8 \\
210,000 and up & 2 & 4 & 50 & 22 \\
Total & 50 & 100 & & 100 \\
\hline
\end{tabular}


Table 7. Indebtedness to financiers.

\begin{tabular}{lllll}
\hline \multirow{2}{*}{ Indebted to } & Hindu fishermen & & Muslim fishermen \\
\cline { 2 - 5 } & Frequency & $\mathbf{\%}$ & Frequency & \% \\
\hline Bank (Government) & 1 & 1.10 & 13 & 13.27 \\
NGO & 37 & 40.66 & 35 & 35.71 \\
Aratdar/ Paiker/ Dadandar & 11 & 12.09 & 18 & 18.37 \\
Local moneylender & 8 & 8.79 & 15 & 15.31 \\
Shopkeeper & 21 & 23.07 & 7 & 7.14 \\
Relative & 13 & 14.29 & 10 & 10.20 \\
Total & 91 & 100 & 88 & 100 \\
\hline
\end{tabular}

\subsection{Coping Options}

Coping options and interest of Hindu and Muslim fishermen are quite different. A total of 30 Hindu fishermen, out of 50 respondents, become jobless during restriction period. Majority of them have psycho-social barrier to change profession. In the Hindu fishing paras (neighborhoods), there is no open space left between the houses. It is even difficult to identify the ownership of one house from the next as the houses are so close to each other.
Table 8 provides multiple answers of fishermen regarding their scope and interest for coping during jatka catching ban period. It is identified that Hindu fishermen don't have diversified opportunities for coping. For instance, they cannot do aquaculture or case culture due to lack of space. Moreover, they live nearby areas of Chittagong city. But their rate of migration for searching job is very low. Majority of them want to involve in similar profession; as for example, catching other species like Chingri (Shrimp), Loitta fish (Bombay duck), and to engage as a fishing labor.

Table 8. Scope and interest of fishers to cope during fishing ban period.

\begin{tabular}{lllll}
\hline \multirow{2}{*}{ Coping } & Hindu fishermen & \multicolumn{2}{l}{ Muslim fishermen } \\
\cline { 2 - 5 } & Frequency & \% & Frequency & \% \\
\hline Loan from different sources & 41 & 44.57 & 32 & 14.04 \\
To catch other species & 15 & 16.30 & 8 & 3.51 \\
Net making / mending & 7 & 7.61 & 4 & 1.75 \\
Aquaculture & - & - & 28 & 12.28 \\
Cage culture & - & - & 13 & 5.70 \\
Poultry and duck rearing & - & - & 24 & 10.53 \\
Small-scale business & 2 & 2.17 & 20 & 8.77 \\
Livestock (goat, sheep, and cow rearing) & - & - & 15 & 6.58 \\
Agricultural work / share cropping & - & - & 22 & 9.65 \\
Day labor & 5 & 5.43 & 30 & 13.16 \\
To reduce expenditure & 9 & 9.78 & 7 & 3.07 \\
Driving (like rickshaw-van, motorcycle, and local-made vehicles) & 2 & 2.17 & 11 & 4.82 \\
Migration to cities & 1 & 1.10 & 8 & 3.51 \\
Fishing labor & 8 & 8.70 & 6 & 2.63 \\
Work in ship-breaking site & 2 & 2.17 & - & - \\
Total & 92 & 100 & 228 & 100 \\
\hline
\end{tabular}

\section{Conclusion}

This field based study finds that the coastal zone is relatively income-poor in comparison with rest of the country. Poverty is the main cause of catching jatka though majority of Hindu fishermen obey restriction rule imposed by government. They are also being put under pressure by incoming Muslims who take up fishing as their profession. Hindu fishermen have limited scope and interest to cope with changed situation. This paper suggests that policy instruments and fishery management of Bangladesh should give special focus on socio-economic \& cultural aspects of those downtrodden people for inclusive development.

\section{References}

[1] Food and Agriculture Organization, 2014, The State of World Fisheries and Aquaculture: Opportunities and challenges, FAO.

[2] World Bank, 2014, Strategic Vision for Fisheries and Aquaculture, The Global Program on Fisheries, WB.

[3] Ministry of Finance 2014, Bangladesh Economic Review 2014, Ministry of Finance (MoF), Government of the People's Republic of Bangladesh.

[4] Department of Fisheries of Bangladesh 2015, About Department of Fisheries, viewed 16 September 2015, fromhttp://www.fisheries.gov.bd/site/page/43ce3767-39814248-99bd-d321b6e3a7e5/Background 
[5] Islam, G. M. N., Yew, T. S., Abdullah, N. M. R., \& Viswanathan, K. K., 2011, Social capital, community based management, and fishers' livelihood in Bangladesh. Ocean and Coastal Management, 54 (2), 173-180.

[6] Deb, Apurba Krishna., 2009, 'Voices of the Fishantry: Learning on the Livelihood Dynamics from Bangladesh', PhD dissertation, Natural Resources and Environmental Management, Natural Resources Institute, University of Manitoba, Canada.

[7] Alam, K., 1996, 'Two fishing villages of Bangladesh: a community study', PhD thesis, Department of Development and Planning, Aalborg University, Fibigerstraede 2, DK- 9220 , Aalborg, Denmark.

[8] Habib, Absar., 1992, Delipara: An Obscure Fishing Village of Bangladesh, CODEC Publication, Chittagong, Bangladesh.
[9] Bangladesh Centre for Advanced Studies, 2010, Access to Fisheries Resources by the Poor Fishers for Income Generation and Livelihood and Their Coping Strategies During Lean and Ban Fishing Period in Bangladesh, BCAS, Dhaka, Bangladesh.

[10] Department of Fisheries 2014, Fisheries Statistical Yearbook of Bangladesh 2012-2013, Fisheries Resources Survey System, Ministry of Fisheries and Livestock, Government of the People's Republic of Bangladesh.

[11] Planning Commission of Bangladesh 2011, Sixth Five Year Plan, FY2011-FY2015, Accelerating Growth and Reducing Poverty, Ministry of Planning, Government of the People's Republic of Bangladesh.

[12] Bay of Bengal Large Marine Ecosystem, 2012, Management advisory for the Bay of Bengal Hilsa fishery, BOBLME, Regional Coordination Unit, Thailand. 